\title{
Urinary nitrogen compounds in dairy cows fed urea as the sole or partial source of nitrogen
}

\author{
Terttu Ettala and Matti Kreula \\ Biochemical Research Institute, Kalevankatu 56 b, 00180 Helsinki 18, Finland
}

\begin{abstract}
Urinary nitrogen compounds were determined in test cows with urea as the sole (0-cows) or partial (ULP-cows) source of nitrogen. An average of $0.49 \%$ total nitrogen was found in 0 -cows and $0.88 \%$ in ULP-cows, the values for urea nitrogen being 2.24 and $2.63 \mathrm{mg} / \mathrm{ml}$, for ammonium nitrogen 0.14 and $0.09 \mathrm{mg} / \mathrm{ml}$, for creatinine 0.77 and $0.90 \mathrm{mg} / \mathrm{ml}$ and for creatine 0.28 and $0.42 \mathrm{mg} / \mathrm{ml}$ urine, respectively. Differences between the two groups were highly significant $(\mathrm{P}<0.001)$ as regards total nitrogen and significant $(\mathrm{P}<0.05)$ as regards urea nitrogen and creatine. In each group the between-cow differences were highly significant with regard to total and urea nitrogen and creatine, and in 0-cows also with regard to ammonium nitrogen and creatinine. Smaller amounts of urinary allantoin and larger amounts of uric acid were found in 0-cows than in ULP-cows. Corresponding determinations were made to some extent also on the urine of cows on normal indoor or pasture feeding.
\end{abstract}

\section{Introduction}

The urinary nitrogen compounds are end products of nitrogen metabolism and they reflect the interrelation between the organism and feeding. The most important of these compounds with ruminants as well as with other mammals, both quantitatively and metabolically, is urea which readily reflects the protein status of the feed and which is influenced by almost all changes occurring in protein metabolism. Urinary urea excretion has been observed to be closely related to the urea content of the blood, for instance with sheep (Cocrmano and Leng 1967, MC InTyRe et al. 1970) and with steers (Thornton 1970). Other nitrogen compounds, excreted in the intermediary metabolism and derived either directly or indirectly from amino acids, are uric acid and creatine. Creatine, which is mainly excreted as creatinine, is formed from arginine, glycine and methionine. Urinary ammonia is derived to a great extent from the acid amide group of glutamine (Носк 1966). In experiments performed with sheep a correlation between the nucleic acids of the rumen and the urinary purine compounds was observed (Topps and ElliotT 1965). Also smaller amounts of lower peptides, amino acids and amino acid derivatives are excreted 
in the urine. Quantitatively the most important amino acid derivative is that of glycine: hippuric acid, which is a detoxication product of benzoic acid.

In the feeding experiments started at the Biochemical Research Institute in 1961 and continued for more than ten years, in which dairy cows were fed purified protein-free feed with urea as the sole nitrogen source (VIRTANEN 1963, 1966, 1971) or feed rich in urea and poor in protein (VIRTANEN 1967 a, 1971), special attention was paid to the nitrogen metabolism of the test cows, and thus also to the urinary nitrogen and nitrogen compounds. In the present paper the contents of total urea and ammonium nitrogen, creatine and creatinine determined on the urine of the test cows during several production periods are presented. Nitrogen balances, as well as contents of uric acid, allantoin and amino acids, were also determined to some extent.

\section{Materials and methods}

All cows sampled were Ayrshires. Urine samples were taken from all dairy cows on a purified protein-free feed with urea (and also ammonium salts to some extent) as the sole source of nitrogen ( 0 -feeding and 0 -cows) and from cows on a feed rich in urea and poor in protein (ULP-feeding and ULP-cows) the minimum being once a month during $2-4$ production periods. For comparison samples were also taken from 30 cows on normal silage-cereals feed and from 20 cows on pasture feed, the common name for both groups being "NorPcows». In connection with the digestibility tests the whole-day urine of the test cows was collected with a "Urinal" harness (VEB Leipziger Gummiwarenfabriken) and the nitrogen balance was determined. The urine samples were deep-frozen immediately after sampling and preserved as such for the determinations.

The following methods were used in the determinations: Total nitrogen was determined by the $\mathrm{Kjeldahl}$ method with $\mathrm{KMnO}_{4}$ according to BEET (1955).

Urea and ammonium nitrogen were determined according to ConwAY (1962).

Creatinine and creatine were determined according to Albanese and Orto (1963) with picric acid in an alkaline solution, based on Jaffe's reaction.

Uric acid was determined enzymatically with uricase enzyme (Uricase Leo, Leo Pharmaceutical Products, Denmark), according to Praetorius (1962) Allantoin was determined according to Young and Conway (1942).

The free amino acids, as well as those of the urine hydrolysate $(6 \mathrm{~N} \mathrm{HCl}$, $20 \mathrm{~h}, 106^{\circ} \mathrm{C}$ ) were purified with Amberlite IR 120 cation exchange resin in $\mathrm{H}^{+}$ form, after which the nitrogen of the amino acid fraction was determined.

\section{Results}

The total urinary nitrogen contents in cows on 0 -feed were much lower than on ULP-feed and the difference was highly significant $(\mathrm{P}<0.001)$, as was the case also between individual cows on each feeding (Table 1). In contrast, the average contents of total nitrogen with both ULP- and NorP-cows were about the same. The differences in the contents of urea nitrogen between various 
Table 1. Nitrogen fractions of the urine of milk-producing 0-, ULP- and NorP-cows

\begin{tabular}{|c|c|c|c|c|c|c|}
\hline & & $\begin{array}{c}\text { Total } \\
\%\end{array}$ & $\begin{array}{c}\text { Urea N } \\
\mathrm{mg} / \mathrm{ml}\end{array}$ & $\begin{array}{l}\mathrm{NH}_{4}-\mathrm{N} \mathrm{C} \\
\mathrm{mg} / \mathrm{ml}\end{array}$ & $\begin{array}{c}\text { Creatinine } \\
\mathrm{mg} / \mathrm{ml}\end{array}$ & $\begin{array}{c}\text { Creatine } \\
\mathrm{mg} / \mathrm{ml}\end{array}$ \\
\hline \multicolumn{7}{|c|}{ I 0-cows: } \\
\hline & Eiru ..... & 0.30 & 1.26 & 0.08 & - & - \\
\hline & 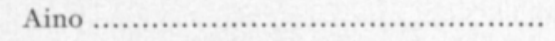 & 0.49 & 2.27 & 0.07 & 1.20 & 0.37 \\
\hline & Jairu ........................................... & 0.47 & 2.35 & 0.11 & 0.84 & 0.25 \\
\hline & Metta ........................................ & 0.70 & 2.63 & 0.15 & 0.90 & 0.31 \\
\hline & 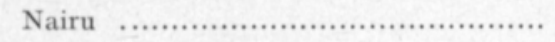 & 0.65 & 2.58 & 0.13 & 0.87 & 0.37 \\
\hline & 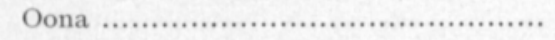 & 0.44 & 2.41 & 0.15 & 0.51 & 0.25 \\
\hline & Pairu ......................................... & 0.57 & 2.34 & 0.33 & 0.72 & 0.23 \\
\hline & Roona ........................................ & 0.31 & 2.10 & 0.11 & 0.36 & 0.15 \\
\hline & Mean values $(n=460) \ldots \ldots \ldots \ldots \ldots \ldots . . . . . .$. & 0.49 & 2.24 & 0.14 & 0.77 & 0.28 \\
\hline & F: (between-cow) ........................... & $15.65^{* * *}$ & $5.59 * * *$ & $8.52 * * *$ & * $14.23^{* * *}$ & $8.23 * * *$ \\
\hline \multirow[t]{10}{*}{ II } & ULP-cows: & & & & & \\
\hline & Lila ....................... & 0.53 & 2.23 & 0.06 & 0.89 & 0.29 \\
\hline & Kelo ............................................. & 1.05 & 3.04 & 0.07 & 0.96 & 0.39 \\
\hline & Lelo ........................................... & 1.03 & 2.40 & 0.20 & 0.91 & 0.48 \\
\hline & Kila .......................................... & 0.82 & 2.38 & 0.05 & 0.82 & 0.53 \\
\hline & 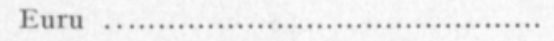 & 1.01 & 3.11 & 0.06 & 1.01 & 0.39 \\
\hline & Kairu ........................................ & 0.83 & 2.64 & 0.08 & 0.81 & 0.41 \\
\hline & Mean values $(n=181) \ldots \ldots \ldots \ldots \ldots \ldots \ldots \ldots$ & 0.88 & 2.63 & 0.09 & 0.90 & 0.42 \\
\hline & 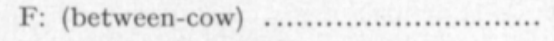 & $15.57^{* * *}$ & $4.53 * * *$ & 1.82 & 1.53 & $7.31^{* * *}$ \\
\hline & F: (groups I and II) ......................... & $26.29 * * *$ & $4.53^{*}$ & 1.57 & 0.95 & $9.51^{*}$ \\
\hline \multicolumn{7}{|c|}{ III NorP-cows: } \\
\hline & Pasture feed $(\mathrm{n}=12) \ldots \ldots \ldots \ldots \ldots \ldots \ldots \ldots \ldots \ldots \ldots \ldots$ & 0.91 & 4.14 & 0.14 & 0.79 & 0.39 \\
\hline & Indoor feed $(\mathrm{n}=25) \quad \ldots \ldots \ldots \ldots \ldots \ldots \ldots \ldots \ldots$ & 0.77 & 2.30 & 0.12 & 0.92 & 0.50 \\
\hline
\end{tabular}

$\mathrm{P}<0.001=* * *, \mathrm{P}<0.01=* *, \mathrm{P}<0.05=*$

individuals both on 0 - and ULP-feed were highly significant, whereas those between various feeding groups were only significant $(\mathrm{P}<0.05)$. The highest urea nitrogen contents were found on pasture feed $(0.41 \%)$ and the lowest on 0 -feed (Eiru $0.13 \%$ ). In spite of the lower urea contents, an average of $53 \%$ of the urinary nitrogen with 0 -cows was urea nitrogen, whereas the average proportion on ULP-feed was $32 \%$. Lila was an exception among the ULPcows: in its urine an average of $50 \%$ of total nitrogen was urea nitrogen (Table 2). The proportion of urea on pasture feed was $49.2 \%$ and on indoor feed $31.6 \%$. As for ammonium nitrogen, highly significant individual differences were observed only with 0 -cows (Table 1 ). The differences in the average ammonium nitrogen contents between the various feeding groups were not significant, The proportion of ammonium nitrogen of the total urinary nitrogen was highest with 0 -cows and lowest with ULP-cows (Table 2).

In the creatinine contents highly significant individual differences between cows occurred on $\mathbf{0}$-feed, but not on ULP-feed (Table 1). The differences in the average values were not significant on 0 - and ULP-feeds, and also the creatinine contents of the urine of NorP-cows were about the same. 
Table 2. Total nitrogen contents and proportions of urea, ammonium and creatinine nitrogen of the total nitrogen content of the urine of milk-producing and dry 0-, ULPand NorP-cows

\begin{tabular}{|c|c|c|c|c|c|c|}
\hline Cows & $\begin{array}{c}\text { Number } \\
\text { of samples }\end{array}$ & $\begin{array}{c}\text { Total } \\
\%\end{array}$ & \multicolumn{4}{|c|}{$\%$ of the total nitrogen } \\
\hline \multicolumn{7}{|l|}{ O-cows: } \\
\hline 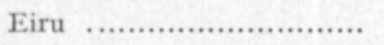 & 83 & $0.21 \pm 0.14$ & $60.9 \pm 16.6$ & $3.1 \pm 2.9$ & $(26)^{*}$ & $15.3 \pm 3.8$ \\
\hline Aino & 98 & $0.48 \pm 0.21$ & $48.4 \pm 12.4$ & $1.3 \pm 1.1$ & (42) & $8.0 \pm 1.6$ \\
\hline Jairu ........................ & 139 & $0.46 \pm 0.17$ & $53.1 \pm 14.8$ & $2.0 \pm 1.4$ & (75) & $8.9 \pm 2.8$ \\
\hline Metta ................... & 115 & $0.66 \pm 0.28$ & $41.8 \pm 13.9$ & $2.1 \pm 1.5$ & $(53)^{-}$ & $8.2 \pm 4.9$ \\
\hline 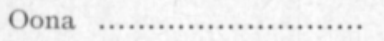 & 37 & $0.33 \pm 0.17$ & $59.6 \pm 16.2$ & $3.4 \pm 2.4$ & (37) & $5.9 \pm 2.5$ \\
\hline 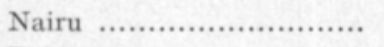 & 60 & $0.65 \pm 0.31$ & $45.0 \pm 14.9$ & $1.9 \pm 1.9$ & $(60)$ & $5.6 \pm 2.4$ \\
\hline Pairu ........................... & 37 & $0.41 \pm 0.24$ & $58.5 \pm 18.4$ & $3.6 \pm 4.4$ & $(37)$ & $6.1 \pm 2.2$ \\
\hline 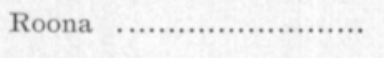 & 26 & $0.29 \pm 0.17$ & $54.5 \pm 18.7$ & $2.1 \pm 1.1$ & (26) & $7.6 \pm 1.9$ \\
\hline \multicolumn{7}{|l|}{$U L P$-cows: } \\
\hline Lila ............................. & 58 & $0.47 \pm 0.27$ & $50.0 \pm 15.4$ & $0.8 \pm 0.6$ & & $8.0 \pm 4.1$ \\
\hline Kelo ............................. & 16 & $1.02 \pm 0.23$ & $30.1 \pm 11.1$ & $0.8 \pm 0.6$ & & $3.8 \pm 1.3$ \\
\hline Lelo ............................. & 32 & $1.08 \pm 0.38$ & $25.4 \pm 8.4$ & $0.8 \pm 1.2$ & & $3.9 \pm 1.6$ \\
\hline Kila .............................. & 30 & $0.79 \pm 0.34$ & $33.2 \pm 11.0$ & $0.8 \pm 1.2$ & & $4.4 \pm 1.6$ \\
\hline Euru ............................ & 30 & $1.00 \pm 0.29$ & $32.5 \pm 15.0$ & $0.9 \pm 1.1$ & & $4.5 \pm 1.4$ \\
\hline Kairu .......................... & 18 & $0.82 \pm 0.31$ & $36.8 \pm 16.2$ & $1.2 \pm 1.4$ & & $4.5 \pm 1.7$ \\
\hline \multicolumn{7}{|l|}{ NorP-cows: } \\
\hline Indoor feeding ............... & 30 & $0.77 \pm 0.35$ & $31.6 \pm 12.3$ & $1.9 \pm 3.3$ & & $4.7 \pm 1.3$ \\
\hline Pasture feeding ................ & 12 & $0.91 \pm 0.36$ & $49.2 \pm 12.6$ & $1.7 \pm 2.0$ & & $3.3 \pm 0.8$ \\
\hline
\end{tabular}

* Number of samples analysed for creatinine.

Table 3. Urinary creatinine contents $(\mathrm{mg} / \mathrm{ml})$ in dry and milk-producing 0-, ULP-and NorP-cows

\begin{tabular}{lll}
\hline Cows & \multicolumn{2}{c}{ Urinary creatinine $\mathrm{mg} / \mathrm{ml}$} \\
& Production period & Dry \\
\hline
\end{tabular}

\section{0-cows}

\begin{tabular}{|c|c|c|c|c|}
\hline 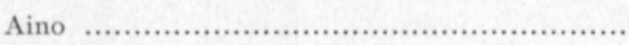 & $(37)$ & $1.2 \pm 0.3$ & $(5)$ & $1.8 \pm 0.6$ \\
\hline Jairu & (17) & $0.8 \pm 0.2$ & (13) & $1.0 \pm 0.2$ \\
\hline Metta .................................................... & (11) & $0.9 \pm 0.2$ & (11) & $1.6 \pm 0.7$ \\
\hline Nairu & (49) & $0.9 \pm 0.5$ & ( 9 ) & $1.1 \pm 0.5$ \\
\hline Oona & $(42)$ & $0.5 \pm 0.2$ & $(7)$ & $1.0 \pm 0.5$ \\
\hline Pairu ............... & $(20)$ & $0.7 \pm 0.2$ & $(24)$ & $0.6 \pm 0.3$ \\
\hline 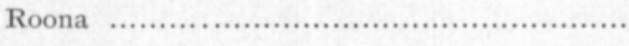 & $(12)$ & $0.4 \pm 0.1$ & $(20)$ & $0.7 \pm 0.4$ \\
\hline \multicolumn{5}{|l|}{ ULP-cows: } \\
\hline Lila ........... & (59) & $0.9 \pm 0.3$ & (16) & $1.0 \pm 0.6$ \\
\hline 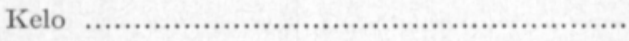 & (14) & $1.0 \pm 0.2$ & $(2)$ & $1.4 \pm 0.3$ \\
\hline Lelo ..................................................... & $(34)$ & $0.9 \pm 0.3$ & ( 3$)$ & $1.5 \pm 0.4$ \\
\hline 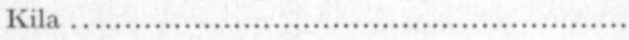 & (23) & $0.8 \pm 0.3$ & ( 6$)$ & $1.0 \pm 0.3$ \\
\hline Euru & (25) & $1.0 \pm 0.2$ & $(7)$ & $1.5 \pm 0.4$ \\
\hline 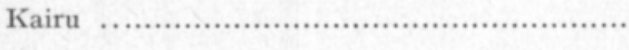 & (14) & $0.8 \pm 0.3$ & (4) & $1.4 \pm 0.4$ \\
\hline \multicolumn{5}{|l|}{ NorP-cows } \\
\hline 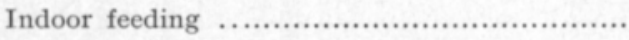 & $(25)$ & $0.9 \pm 0.4$ & ( 4$)$ & $1.4 \pm 0.7$ \\
\hline Pasture feeding ...................................... & (12) & $0.8 \pm 0.3$ & no $\mathrm{d}$ & terminations \\
\hline
\end{tabular}


As for the creatine contents, highly significant differences occurred between individual cows on 0 - and ULP-feeds. The difference in the average values of various feeding groups was significant $(\mathrm{P}<0.05)$.

With dry cows the urinary creatinine content was higher than with milkproducing cows (Table 3 ) and it rose when the production period exceeded twelve months. The contents of total nitrogen, urea and ammonium nitrogen were lower with dry cows than with milk-producing cows.

Allantoin nitrogen was determined on the urine of four 0-cows and four ULP-cows. The urinary allantoin content $(\mathrm{mg} / \mathrm{ml}$ urine) in ULP-cows was higher than in 0 -cows, but the proportion of allantoin-nitrogen of the total nitrogen was lower than in 0 -cows (Table 4). Urinary uric acid in 0 -cows was higher than in ULP-cows, as was also the proportion of uric acid-nitrogen of the total nitrogen.

The proportion of the nitrogen of the free amino acids of the total urinary nitrogen was $6.0 \%$ with 0 -cows, $5.0 \%$ with ULP-cows and $10.5 \%$ with NorPcows. The nitrogen content of the amino acids of the hydrolysate was $8.6 \%$ of the total nitrogen with 0 -cows, $10.0 \%$ with ULP-cows and $20.0 \%$ with NorP-cows.

Table 4. Urinary uric acid and allantoin contents in 0- and ULP-cows

\begin{tabular}{|c|c|c|}
\hline & 0 -cows & ULP-cows \\
\hline Uric acid $\mathrm{mg} / \mathrm{ml}$.................................... & $1.06 \pm 1.05$ & $0.19 \pm 0.08$ \\
\hline 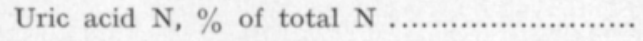 & $9.5 \pm 5.7$ & $0.9 \pm 0.3$ \\
\hline 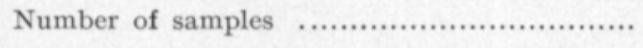 & 30 & 11 \\
\hline 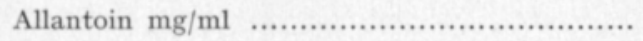 & $1.50 \pm 0.51$ & $1.85 \pm 0.61$ \\
\hline 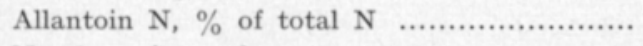 & $12.2 \pm 5.0$ & $9.6 \pm 2.7$ \\
\hline 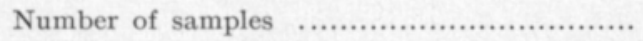 & 20 & 12 \\
\hline
\end{tabular}

Table 5. Daily excretion of nitrogen in the urine of test cows

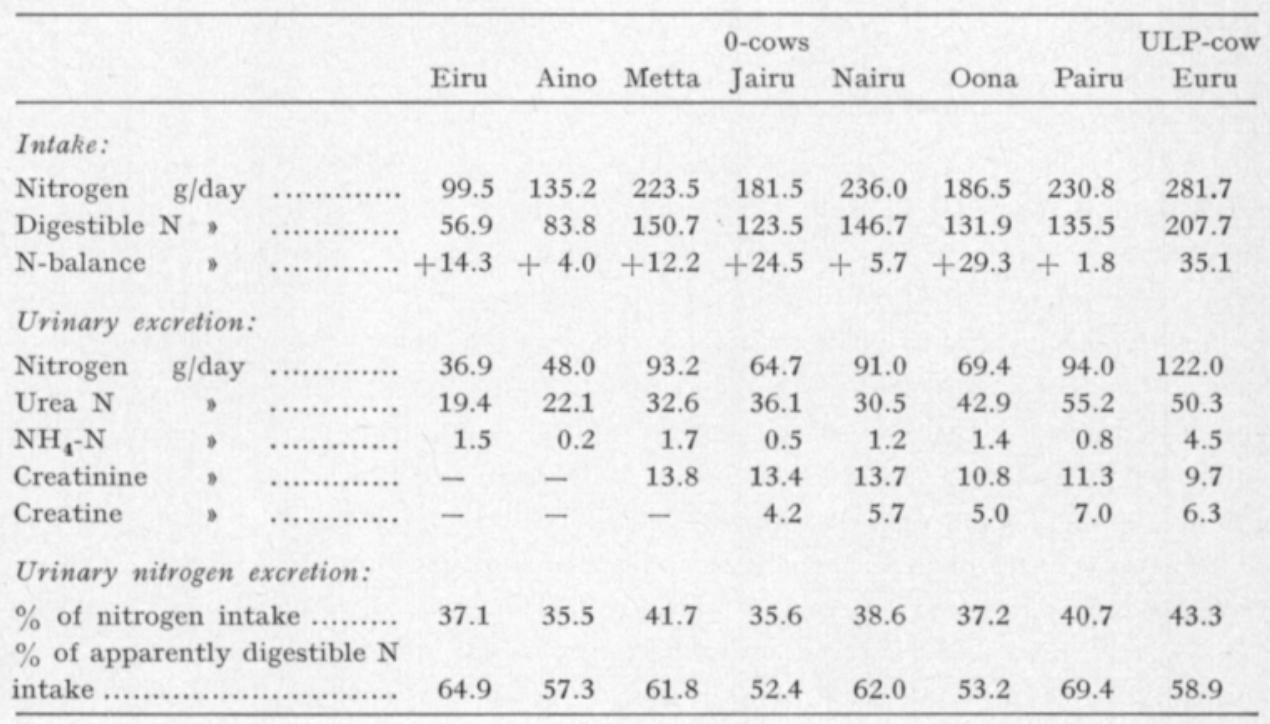


Table 6. Amounts of milk and urine and consumption of water found in nitrogen balance experiments with test cows

\begin{tabular}{|c|c|c|c|}
\hline Cow & $\begin{array}{l}\text { Milk } \\
\mathrm{kg} / \text { day }\end{array}$ & $\begin{array}{c}\text { Urine } \\
\mathrm{kg} / \text { day }\end{array}$ & $\begin{array}{c}\text { Consumption } \\
\text { of water } \\
\text { kg/day }\end{array}$ \\
\hline \multicolumn{4}{|l|}{ O-cows: } \\
\hline Eiru ......................... & 6 & 22 & 45 \\
\hline 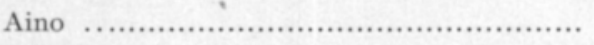 & 4 & 15 & 42 \\
\hline Jairu & 5 & 17 & 45 \\
\hline Metta ............................................... & 5 & 15 & 29 \\
\hline Nairu & 7 & 15 & 33 \\
\hline Oona & 10 & 15 & 51 \\
\hline Pairu & 6 & 30 & 56 \\
\hline ULP-cow Euru ................................... & 11 & 10 & not determined \\
\hline
\end{tabular}

In all nitrogen balance experiments the results were positive. With 0 -cows $35.5-41.7 \%$ of the nitrogen intake and $52.4-69.4 \%$ of the digestible nitrogen intake was recovered in the urine. The corresponding figures for ULP-cow Euru were $43 \%$ and $59 \%$ (Table 5 ). Of this nitrogen the daily excretion of urea nitrogen was $19-55 \mathrm{~g}$ with 0 -cows and that of ammonium nitrogen less than $2 \mathrm{~g}$. The corresponding figures for the ULP-cow were $50 \mathrm{~g}$ and $4.5 \mathrm{~g}$.

With each individual cow the daily excretion of creatinine was constant, whereas differences occurred between various individuals. The amounts of creatine per day varied also with the same cow. In table 6 the average consumption of water with 0 -cows is presented. The table also shows the average amount of urine excreted per day. The consumption of water with ULP-cows was not determined and the daily amount of urine $(24 \mathrm{~h})$ was determined only on test cow Euru, being $10 \mathrm{~kg}$.

\section{Discussion}

\section{Total, urea and ammonium nitrogen}

The total urinary nitrogen and urea nitrogen contents were lower with 0 -cows than with ULP- and NorP-cows. In total nitrogen the differences were highly significant $(\mathrm{P}<0.001)$ and in urea nitrogen only significant $(\mathrm{P}<0.05)$. The differences between individual cows as regards total and urea nitrogen were highly significant on 0 - and ULP-feeds. Eiru, the first cow on 0 -feed, had the lowest total and urea nitrogen contents $(0.30 \%$ total nitrogen and $0.13 \%$ urea nitrogen). Eiru was fed smaller amounts of urea than the cows later included in the test, because the cows were fed very cautiously due to the risk of ammonia poisoning. In spite of this the nitrogen balance was positive. There may have been an effective re-diffusion of urea in the kidney (ScmidTNielsen et al. 1958, Virtanen 1967 b, Mc Intyre et al. 1970). When the amount of urea fed to the 0 -cows was increased, the total urinary and urea nitrogen contents increased, and also the proportion of urea nitrogen of the 
total nitrogen (Figures 1 and 2). Many scientists have found the same thing as regards cows on normal feeding, irrespective of whether the cows are pregnant, dry or milk-producing (Livingston et al. 1962, NeHring et al. 1965, Kertz 1970, Robinson et al. 1973, PAQue et al. 1973). Kertz has observed that the total urinary and urea nitrogen are influenced both by nitrogen intake and nitrogen requirement. PAQUE et al. (1973) found that $27-77 \%$ of the digestible nitrogen fed was excreted in the urine of milk-producing cows and more than $60 \%$ in the urine of dry cows. Both on 0 - and ULPfeeds the nitrogen balance was positive in all tests and on 0 -feed 52-69\% of the digestible nitrogen was excreted in the urine and on ULP-feed (test cow Euru) $59 \%$.

With human beings (Rose et al. 1950, 1951) and rats (KIRIYAMA et al. 1967) the quality of protein has been observed to influence the proportion of urea nitrogen of the total urinary nitrogen in such a way that with a diet well balanced in regard to amino acids the proportion of urea-nitrogen has decreased. It has been found that with sheep both deficiency and excess of methionine have increased the total urinary nitrogen and urea excretion (TAO et al. 1974) thus causing a negative nitrogen balance (Schelling et al. 1973). Kim et al. (1971) have observed that the amount of nitrogen excreted in the urine of milking cows increased and the nitrogen balance decreased when cows were fed methioninehydroxy analog. Mäkinen (1972) found that in the plasma of 0 -cows there were smaller amounts of all essential amino acids except threonine and tryptophan, and larger amounts of glycine than in the plasma of NorPcows. In spite of this the proportion of urea nitrogen of the total urinary nitrogen was the same with 0 -cows as with NorP-cows on pasture feed, and the nitrogen balance was positive. With ruminants, in which protein is also produced by rumen bacteria, the quality of the protein fed obviously is not as important as with non-ruminants. BINES and BALCH (1973) have not found any signifi-

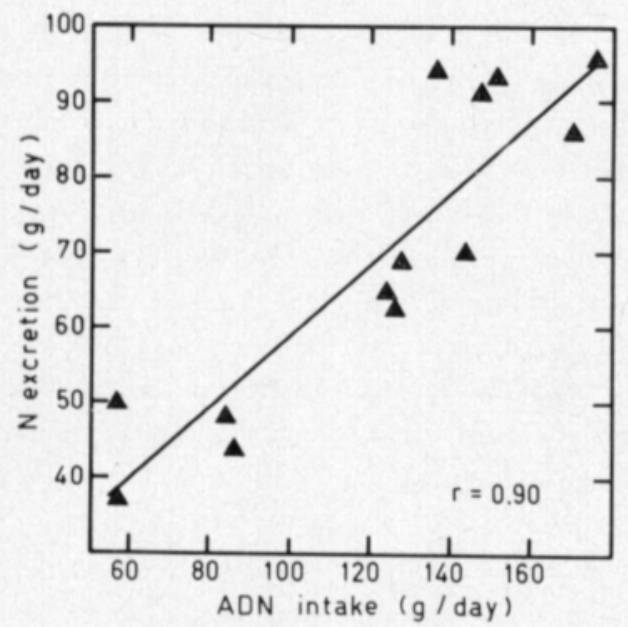

Fig. 1. Effect of apparently digestible nitrogen (ADN) intake on the total urinary nitrogen excretion in 0 -cows.

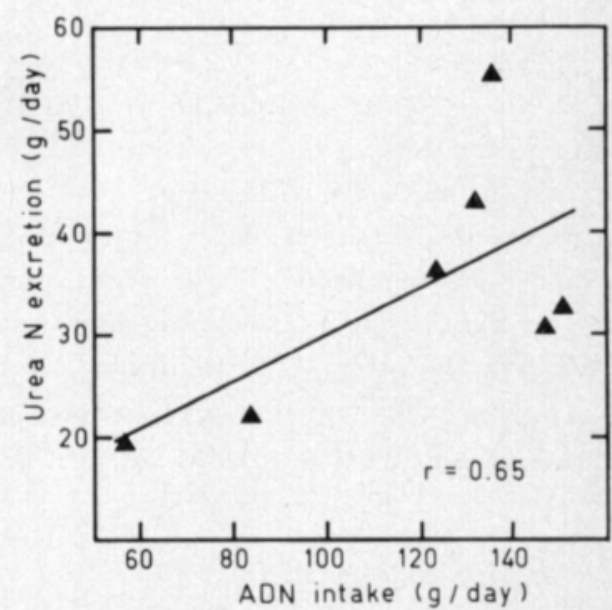

Fig. 2. Effect of apparently digestible nitrogen (ADN) intake on the urinary urea nitrogen excretion in 0 -cows. 
cant difference between peanut meal and urea as to their effect on the amoun of urinary nitrogen excretion, and on the nitrogen balance. Neither have significant differences been found between soya and urea when cows have first been adapted to the use of urea (LuDwick et al. 1971). According to PAQUE et al. (1973) the amount of urinary nitrogen excretion is also influenced by the amount of digestible dry matter. The composition of dry matter has also been observed to effect the amount of nitrogen in the urine (ScHiEmann et al. 1965, Pfeffer et al. $1975 \mathrm{a}, 1975 \mathrm{~b})$ so that the addition of sugar, cellulose or starch to the feed has decreased the amount of total urinary nitrogen and also the proportion of urea nitrogen. On the basis of the results obtained by the above scientists a conclusion could be drawn that the low total nitrogen content of the urine of 0 -cows is due to the fact that 0 -feed contains only purified carbohydrates as a source of energy: starch, cellulose and sugar. OLtJEN et al. (1965) have also stated that the total urinary nitrogen content in cows on purified feed has been lower than that in cows on normal feed. On the other hand the urinary urea nitrogen proportion in 0 -cows was higher than that in most ULP-cows and NorP-cows on indoor feeding, but about the same as that in NorP-cows on pasture feeding, and in ULP-cow Lila. The diet of ULP-cow Lila contained urea to such an extent that it supplied $60-$ $65 \%$ of the digestible crude protein required. Schiemann et al. (1965) and PFEFFER et al. (1975) used steers and wethers as test animals instead of dairy cows. In experiments performed with sheep (Cocrmano and LENG 1967, Mc INTYRE et al. 1970) and steers (THORNTON 1970) it was observed that the urinary urea excretion was closely related to the urea content of the plasma. In her studies MÄKINEN (1972) found that the urea content of the plasma was the lowest in the blood of 0 -cows and the highest in that of NorP-cows. The average urea content of the urine of 0 -cows was, however, the same as that of NorP-cows on indoor feeding. Comparable data about the daily amount of urinary urea excretion is available only as regards 0 -cows, because for this study whole-day urine was collected from all 0 -cows, one ULP-cow and no NorP-cows.

Elliott and Topps (1963) and Juhasz (1971) have observed that the amount of crude protein of the feed influences the urinary ammonia content. However, no significant differences were observed in the ammonia contents of the urine of 0 -, ULP- and NorP-cows. Smaller amounts of total, urea and ammonium nitrogen were found in the urine of dry cows on 0 -, ULP- and NorP-feeds than in the urine of milk-producing cows. One reason for this might be the decrease in the amount of nitrogen intake when the cows are dry. On the other hand RoBinson et al. (1973) have found in their experiments with sheep that at each protein level used the total urinary nitrogen was lower with pregnant sheep than with non-pregnant ones.

\section{Creatinine and creatine}

The differences in the urinary creatinine contents between individual 0 -cows were highly significant, but the differences in the average values between various feeding groups were not significant. The daily amount of creatinine 
excretion was about constant with each test cow. Several other scientists have also observed that the daily amount of creatinine excretion with each individual is the same, whereas there are remarkable variations between different cows (Aafjes and De Groot 1961, Van Niekerk et al. 1963, Albin and Clanton 1966, Kertz et al. 1970). Malory et al. have observed (1970) that the nitrogen intake does not have any effect on the excretion of creatinine. According to Schiemann et al. (1965) an addition of protein decreases the creatinine excretion. KERTZ et al. (1970) have studied the effect of feeding varying amounts of nitrogen to dairy cows and also the effect of time of day on creatinine excretion and also on the creatinine: nitrogen ratio. The amount of nitrogen and the time of day influenced the concentration of creatinine and nitrogen, and their ratio as well, but not the daily creatinine excretion.

On the other hand, according to VAN NIEKERK et al. (1963), sudden variations in the amount of protein intake have an effect on creatinine excretion. The daily amount of urinary creatinine rises when protein is added to the feed. Yокота (1964) has observed that when small amounts of casein were included in the diet of a rat, methionine and glycine caused increased creatinine excretion, whereas arginine had no effect at all. According to FISCHER (1966) the lack of arginine did not have any effect on creatinine excretion, either, whereas a deficiency in all other amino acids, with the exception of lysine and threonine, decreased its excretion. MäkINEN (1972) found that in the blood plasma of 0 -cows there are smaller amounts of arginine and methionine and larger amounts of glycine than in the plasma of NorP-cows. Differences in the amounts of these amino acids necessary for the formation of creatinine are not reflected in the creatinine contents of the urine of 0 -cows.

According to VAN NIEKERK (1963) variations in the energy intake do not influence creatinine excretion. In the studies of PFEFFER et al. (1975 a, $1975 \mathrm{~b})$ with wethers, the addition of starch to the feed did not, either, change the daily creatinine excretion. On the other hand, the proportion of creatine plus creatinine nitrogen of the total urinary nitrogen rose, because the addition of starch decreased the total urinary nitrogen content.

With dry 0 - and ULP-cows the urinary creatinine content was higher than during the milk production period. Similar results were obtained with NorPcows on indoor feeding. No results are available concerning dry cows on pasture feed. Also Albin and Clanton (1966) have made observations on the effect of the lactation stage on creatinine excretion.

As regards creatine, the differences between 0 - and ULP-groups were significant, and between individual cows highly significant. According to the studies of AAFJES and DE GROOT (1961) both the lactation stage and the amount of feed as well as its energy content influence the urinary creatine content.

\section{Allantoin and uric acid}

The allantoin contents of the urine of 0 -cows were lower and the uric acid contents higher than the corresponding contents in the urine of ULP-cows, their combined contents being higher with 0 -cows than with ULP-cows. The proportions of allantoin nitrogen and uric acid nitrogen of the total urinary 
nitrogen were higher with 0 -cows than with ULP-cows. It is probable that most of the allantoin and uric acid excreted by ruminants is derived from the nucleic acids of the rumen microbes (TopPS and ElliotT 1965). This is supported by the studies of BLAXTER and MARTin (1962), according to which casein, when added to the rumen, causes somewhat greater allantoin excretion than when added to the abomasum. In their studies with sheep TopPS and ELLIOTT (1965) have observed a highly significant correlation between the urinary purine derivatives and the ruminal nucleic acids. They found the largest amounts of nucleic acid and purine with feeding at the highest energy level. In their previous experiments with African cattle Elliot and Topps (1963) have stated that when the feed contains adequate energy, but only small amounts of protein, urea excretion in the urine decreases and allantoin excretion increases so much that allantoin becomes the main component of the urinary nitrogen compounds. According to them urea returns effectively to the rumen via the saliva with African cattle which are able to live on very small amounts of protein. If an easily fermented source of energy is then available, the microbial function in the rumen is effective. In their experiments uric acid excretion decreased when the amount of feed protein decreased. Schiemann et al. (1965) have observed that when the nitrogen in the feed of steers increased the proportion of allantoin and uric acid of the total nitrogen decreased. When the sugar and cellulose contents in the feed rose the proportion of allantoin and uric acid increased. The same is the case when the starch content of the feed rises (Pfeffer et al. 1975 a, b).

\section{Urinary amino acids}

The proportion of the total urinary nitrogen present in the amino acids in free form was $6.0 \%$ with 0 -cows, $5.0 \%$ with ULP-cows and $10.5 \%$ with NorP-cows. The proportions of the nitrogen in the amino acids of the hydrolysate were $8.6 \%, 10.0 \%$ and $20.0 \%$ respectively. The total amount of amino acids excreted both in a free and bound form was smaller with the test cows than with NorP-cows. These differences are mainly due to glycine, of which much larger amounts were excreted on NorP-feed than on either of the test feeds. The excretion of amino acids will be discussed in detail in a later publication.

\section{Summary}

The total nitrogen, urea and ammonium nitrogen, creatinine and creatine contents of the urine of cows on a purified protein-free feed with urea and ammonium nitrogen as the sole sources of nitrogen $(0$-feed) and on a feed rich in urea and poor in protein (ULP-feed) were followed by taking samples at least once a month during 2-4 lactation periods. Corresponding determinations were also made on the urine of cows on normal feed (NorP-feed) both during the indoor and outdoor feeding periods. The contents of amino acid, uric acid and allantoin in the urine of some 0 -cows and ULP-cows were also determined. The daily contents of total, urea and ammonium nitrogen and 
creatinine and creatine of the urine of 0 -cows and one ULP-cow were determined, too.

During the lactation period the total urinary nitrogen content in 0 -cows was $0.49 \%$, in ULP-cows $0.88 \%$ and in NorP-cows on indoor feeding $0.77 \%$ and on pasture feeding $0.91 \%$. The differences between individual cows and between 0 - and ULP-groups were highly significant $(\mathrm{P}<0.001)$. The urea nitrogen contents ( $\mathrm{mg} / \mathrm{ml}$ urine) in the urine of 0 -, ULP- and NorP-cows both on indoor and pasture feeding were $2.24,2.63,2.30$ and 4.12 , respectively, and the ammonium nitrogen contents $0.14,0.09,0.12$ and $0.14 \mathrm{mg} / \mathrm{ml}$. The differences between individual cows on 0 - and ULP feeds were highly significant $(\mathrm{P}<0.001)$, and the differences between the means of these groups were significant $(\mathrm{P}<0.05)$ as regards urea. In ammonium nitrogen there were differences only between individual cows $(\mathrm{P}<0.001)$ on 0 -feed.

The contents of creatinine and creatine were 0.77 and 0.28 ( 0 -feed), 0.90 and 0.42 (ULP-feed), 0.92 and 0.50 (NorP-indoor feeding) and 0.79 and 0.39 $\mathrm{mg} / \mathrm{ml}$ (NorP-pasture feeding). Highly significant between-cow differences occurred on 0 -feed and in regard to creatine also on ULP-feed. The differences between the groups were not significant concerning the contents of urinary creatinine, but the average urinary creatine content in 0 -cows was significantly $(\mathrm{P}<0.05)$ lower than that in ULP-cows.

The urine of dry cows contained more creatinine and other nitrogen compounds and less total nitrogen than the urine of milk-producing cows.

The urinary uric acid content in 0 -cows was $1.06 \mathrm{mg} / \mathrm{ml}$ and $0.19 \mathrm{mg} / \mathrm{ml}$ in ULP-cows, and the proportion of its nitrogen was $9.5 \%$ and $0.9 \%$ of the total urinary nitrogen, respectively.

The urinary allantoin content in 0 -cows was 1.50 and in ULP-cows 1.85 $\mathrm{mg} / \mathrm{ml}$, and the proportion of allantoin nitrogen of the total urinary nitrogen was $12.2 \%$ and $9.6 \%$, respectively.

The proportion of the urinary nitrogen in the amino acids in free form was $6.0 \%$ with 0 -cows, $5.0 \%$ with ULP-cows and $10.5 \%$ with NorP-cows. The proportions of the nitrogen in the amino acids of the hydrolysate were $8.6 \%$, $10.0 \%$ and $20.0 \%$, respectively.

The urinary nitrogen in 0 -cows was $35-41 \%$ of the nitrogen intake and $52.4-69.4 \%$ of the digestible nitrogen intake. Of the urinary nitrogen $33.5-61.8 \%$ was urea nitrogen. The urinary nitrogen excretion in ULP-cow Euru was $43.3 \%$ of the nitrogen intake and $58.9 \%$ of the digestible nitrogen intake. Of the urinary nitrogen $41.2 \%$ was urea nitrogen.

\section{REFERENCES}

AAfJes, J. H. \& DE Groot, T. 1961. Creatinine and creatine in the urine of cows. Tijdschr. Diergeneesk. 86: 1436-1443 (ref. Nutr. Abstr. Rev. 32: 476).

Albanese, A. \& Orto, L. A. 1963. Newer Methods of Nutritional Biochemistry p. 88. New York.

Albin, R. C. \& Clanton, D. C. 1966. Factors contributing to the variation in urinary creatinine and creatinine-nitrogen ratios in beef cattle. J. Anim. Sci. 25: 107-112. 
BEeT, A. E. 1955. Potassium permanganate in the Kjeldahl method for the determination of nitrogen in organic substances. Nature 175: $513-514$.

Bines, J. A. \& BaLch, C. C. 1973. Relative retentions of the nitrogen of urea and groundnut in isoenergetic diets for growing heifers. Brit. J. Nutr. 29: 457-466.

Blaxter, K. L. \& Martin, A. K. 1962. The utilization of protein as a source of energy in fattening sheep. Brit. J. Nutr. 16: 397-407.

Cocimano, M. R. \& Leng, R. A. 1967. Metabolism of urea in sheep. Brit. J. Nutr. 21: 353-371.

Conway, E. J. 1962. Microdiffusion Analysis and Volumetric Error. p. 111, 162. London.

Elliotr, R. C. \& Topps, J. H. 1963. Nitrogen metabolism of African cattle fed diets with an adequate energy, low-protein content. Nature 197: 668-670.

Fischer, H. 1966. Effect of amino acid deficiency or excess on creatinine excretion of rats. Zeitschrift für Ernährungswissenschaft 7: 9-16.

Носк, А. 1966. Vergleichende Ernährungslehre des Menschen und seiner Haustiere p. 291. Jena.

JuHAsz, B. 1971. Some aspects of N-metabolism. Tracer Stud. Non-protein Nitrogen, Ruminants, Proc. Panel IAEA, Vienna, 101-105.

Kertz, A. F., Prewitt, L. R., Lane, A. G. \& Campbell, J. R. 1970. Effect of dietary protein intake on creatinine excretion and the creatinine-nitrogen ratio in bovine urine. $\mathrm{J}$. Anim. Sci. 30: 278-282.

Krm, C. W., Holter, J. B., Colovos, N. F. \& Urban, W. E. 1971. Effect of methioninehydroxy analog (MHA) on milk yield and ration utilization. J. Dairy Sci. 54: 1240.

Kiriyama, S., Yagishita, T., Suzuki, T. \& Iwao, H. 1967. The surveys on the urea and allantoin excretion and other criteria from rats fed sthreonine imbalanced, or scorrected diet. Agric. Biol. Sci. 31: 743-749.

Livingston, H. G., PAyne, W. J. A. \& Friend, M. T. 1962. Urea excretion in ruminants. Nature 194: 1057-1058.

Ludwick, R. L., Fontenot, J. P. \& Tucker, R. E. 1971. Studies of the adaptation phenomenon by lambs fed urea as the sole nitrogen source: digestibility and nutrient balance. J. Anim. Sci. 33: 1298-1305.

Maloiy, G. M. O., Kay, R. N. B., Goodall, E. D. \& Topps, J. H. 1970. Digestion and nitrogen metabolism in sheep and red deer given large or small amounts of water and protein. Brit. J. Nutr. 24: 843-855.

McIntyre, K. H. \& Williams, V. J. 1970. The role of the kidney in nitrogen conservation in sheep. Austr. J. Exp. Biol. Med. Sci. 48: 81-91.

MäKrNEn, S. 1972. Aspects of the nitrogen metabolism and nutritional status of urea fed dairy cattle. Ann. Acad. Sci. Fennicae A. II. Chem. 165: 1.

Nehring, K., Zelck, U. \& Schiemann, R. 1965. Uber die Zusammensetzung des Harns an organischen Inhaltstoffen bei Rindern, Schafen und Schweinen. 2. Arch. Tierernähr. 15: $45-51$.

Oltjen, R. R., Putnam, P. A. \& Davis, R. E. 1965. Salivary and metabolic studies with steers fed pelleted or unpelleted conventional and purified rations. J. Anim. Sci. 24: 1126-1130.

Paquay, R., Godeau, J. M., De Paere, R. \& Lousse, A. 1973. Utilization of nutrients by the dairy cow and optimal N:energy ratio in the diet. J. Dairy Res. 40: 329-337.

Pfeffer, E., Mohme, H. \& Kummer, K-F. 1975 a. Untersuchungen über den Einfluss steigender Tapiokazulagen auf den Stickstoffumsatz von Hammeln. Z. Tierphysiol. Tierernähr. Futtermittelkde 35: 93-100.

- - Klapsing, J. \& Besecke, C. 1975 b. Untersuchungen über der Einfluss von Zulagen verschiedener Kohlenhydrate oder flüchtiger Fettsäuren auf den Stickstoffumsatz von Hammeln. Z. Tierphysiol. Tierernähr. Futtermittelkde 35: 101-112.

Praetorius, E. 1962. Methoden der enzymatischen Analyse. p. 500, Weinheim.

Robinson, J. J., Scotr, D. \& Fraser, C. 1973. Observations on the effect of protein intake and stage of gestation on the proportion of urinary nitrogen excreted as urea in sheep. J. Agric. Sci. Camb. 80: 363-368.

Rose, W. C., Johnson, J. E. \& Haines, W. J. 1950. The amino acid requirements of man. 1. J. Biol. Chem. 182: 541-555.

- - Haines, W. J., Warner, D. T. \& Johnson, J. E. 1951. The amino acid requirements of man. 2. J. Biol. Chem. 188: 49-58. 
Schelling, G. T., Chandler, J. E. \& Scotr, G. C. 1973. Postruminal supplemental methionine infusion to sheep fed high quality diets. J. Anim. Sci. 37: 1034-1039.

Schiemann, R., Zelck, U. \& Nehring, K. 1965. Uber die Zusammensetzung des Harns an organischen Inhaltstoffen bei Rindern, Schafen und Schweinen. Arch. Tierernähr. 15: $81-91$.

Schmidt-Nielsen, B. \& OsAKI, H. 1958. Renal response to changes in nitrogen metabolism in sheep. Amer. J. Physiol. 193: 657-661 (ref. Nutr. Abstr. Rev. 29: 2552).

TAO, R., Asplund, J. M. \& KAPPEL, L. C. 1974. Response of nitrogen metabolism, plasma amino acids and insulin levels to various levels of methionine infusion in sheep. J. Nutr. 104: 1646-1656.

Thornton, R. F. 1970. Factors affecting the urinary excretion of urea nitrogen in cattle. 2. The plasma urea nitrogen concentration. Austr. J. Agric. Res. 21: 145-152.

Topps, J. H. \& Elliotr, R. C. 1965. Relationship between concentration of ruminal nucleic acids and excretion of purine derivatives by sheep. Nature 205: 498-499.

van Niekerk, B. D. H., Bensadoun, A., Paladines, O. L. \& Reid, J. T. 1963. A study of some of the conditions affecting the rate of excretion and stability of creatinine in sheep urine. J. Nutr. 79: 373-380.

Virtanen, A. I. 1963. Produktion der Kuhmilch ohne Protein mit Harnstoff und Ammoniumsalzen als Stickstoffquelle und gereinigten Kohlenhydraten als Energiequelle. Biochem. Z. 338: 443-453.

- -1966 . Milk production of cows on protein-free feed. Science 153: 1603-1614.

- -1967 a. Milk production on a protein-free and protein-poor feed. Neth. Milk Dairy J. 21: $223-244$.

$-1967 \mathrm{~b}$. The production of milk on protein-free rations. Urea as Protein Supplement. p. 185-212. Oxford.

- -1971 . Protein requirements of dairy cattle - artificial nitrogen sources and milk production. Milchwiss. 26: 129-138.

Үокота, F. 1964. Effect of excess glycine on rats. 2. Amino acids and creatinine in urine of rats fed of excess glycine diet. Jap. J. Nutr. 22: 193-197. (Ref. Newer Methods of Nutritional Biochemistry IV, p. 51. New York.)

Young, E. G. \& Conway, C. 1942. On the estimation of allantoin by the Rimini-Schryver reaction. J. Biol. Chem. 142: 839-853.

Ms received June 16, 1976

\section{SELOSTUS}

\section{Virtsan typpiyhdisteistä lypsylehmillä urean ollessa ruokinnan ainoana tai osittaisena typenlähteenä}

Tertru Etrala ja Matti Kreula

Biokemiallinen Tutkimuslaitos, Kalevankatu 56 b, 00180 Helsinki 18

Virtsan typpiyhdisteitã on määritetty koelehmiltä, joilla urea on ollut ainoana (0-lehmät) tai osittaisena (ULP-lehmät) typenlähteenä. Kokonaistyppeä on ollut keskimäärin $0.49 \%$ 0-lehmillä ja $0.88 \%$ ULP-lehmillä, ureatyppeä vastaavasti 2.24 ja $2.63 \mathrm{mg} / \mathrm{ml}$, ammoniumtyppeä 0.14 ja $0.09 \mathrm{mg} / \mathrm{ml}$, kreatiniinia 0.77 ja $0.90 \mathrm{mg} / \mathrm{ml}$ sekä kreatiinia 0.28 ja $0.42 \mathrm{mg} / \mathrm{ml}$ virtsaa. Ryhmien väliset erot ovat olleet erittäin merkitseviä $(\mathrm{P}<0.001)$ kokonaistypen ja merkitseviä $(\mathrm{P}<0.05)$ ureatypen ja kreatiinin suhteen. Kummassakin ryhmässä ovat yksilöiden väliset erot olleet erittäin merkitseviä kokonaistypen, ureatypen ja kreatiinin, 0lehmillä myös ammoniumtypen ja kreatiniinin suhteen. Allantoiinia on 0-lehmien virtsassa ollut vähemmän ja virtsahappoa enemmän kuin ULP-lehmien. Tavanomaisella sisä- tai laidunruokinnalla olleiden lehmien virtsoista on vastaavia määrityksiä tehty jonkin verran. 